\title{
A RE-EXAMINATION OF JOHN SHIRLEY'S COLLECTION OF TASMANIAN LICHENS
}

\author{
by Gintaras Kantvilas
}

(with one table and one plate)

\begin{abstract}
KANTVILAS, G., $1988(31: x)$ : A re-examination of John Shirley's collection of Tasmanian lichens. Pap. Proc. R. Suc. Tusm. 122(2): 59-67. https://doi.org/10.26749/rstpp.122.2.59 ISSN ()()8()-47()3. Department of Botany, University of Tasmania, G.P.๑. Box 2526 Hobart. Tasmania, Australia 7(0)1.

The Tasmanian lichen collection of John Shirley (1849-1922) (housed in the Queensland Herbarium) is examined and re-determined. Two new combinations, Rinodina asperata (Shirley) Kantvilas and Pyrenula goslactina (Shirley) Kantvilas, are proposed, and lectotypes are set up for Bacidia weymouthii (Shirley) Zahlbr. and Pyrenula chloroplaca Shirley from authentic material. Several lichen records are based on misidentifications and are deleted from the checklist of Tasmanian lichens.
\end{abstract}

Key Words: Shirley, lichens, Tasmania.

\section{INTRODUCTION}

John Francis Shirley was born in Dorchester, England, on 11 August 1849 and died in Brisbane. Australia, on 5 April 1922. He graduated with a Bachelor of Science degree from the University of London where he qualified as a teacher. In 1878, he emigrated to Queensland and was appointed headmaster at Roma in the south of the colony. He became a school inspector in 1879, a position which enabled him to travel widely and which complemented his love of the outdoors and his interests in natural history. He soon became a prominent figure in Australian scientific circles and ultimately became a member of many scientific societies including the Australasian Association for the Advancement of Science (AAAS), the Royal Society of Queensland, the Queensland Field Naturalists, and the Linnaean Society of New South Wales. He published over 40 papers on botany, conchology, zoology and geology. His major work was "The Lichen Flora of Queensland" (Shirley 1888-9()) which established him as one of Australia's foremost lichenologists. His dedication to lichenology is perhaps best demonstrated by the fact that whilst on long-service leave he studied this subject for a Doctor of Science degrec at Sydney University. He gained his doctorate in 1912 (at the age of 6.3) and his thesis, entitled "The thallus of the genus Parmelia" was subsequently published in Tasmania (Shirley 1918. see also Basset Hull 1923, White 1922).
Shirley's association with Tasmania began in 1892 when he visited Hobart for a meeting of the AAAS, held on 7-16 January. There he studied plants on nearby Mt Wellington and made the acquaintance of William Anderson Weymouth, one of the leading amateur cryptogamic botanists in Tasmania at that time (Kantvilas 1983). In the same year, he became a corresponding member of the Royal Society of Tasmania. His first paper on Tasmanian lichens was a checklist, compiled from earlier literature (Shirley 1893); his second (Shirley 1894), based on his own and Weymouth's collections, represents a major contribution to Tasmanian lichenology. In it he described seven new species and one new variety, and recorded 47 additional species from Tasmania, 13 for the first time.

The bulk of Shirley's collection of Tasmanian lichens is housed in the Queensland Herbarium (BRI) but additional specimens are also known from the National Herbarium of New South Wales (NSW). National Herbarium of Victoria (MEL), and the Conservatoire et Jardin Botanique Genève $(G)$. The lichens are mounted in a large album also containing flowering plants and ferns, which is entitled "Tasmanian Plants Collected on the Slopes and Summit of Mt Wellington, January 1892" (plate 1). Although most of the specimens are from Mt Wellington, a few, especially the lichens, are from other Tasmanian localities, e.g. Tasman Peninsula, Bellerive and Henty River, and represent collections given to Shirley by Weymouth. In fact, 

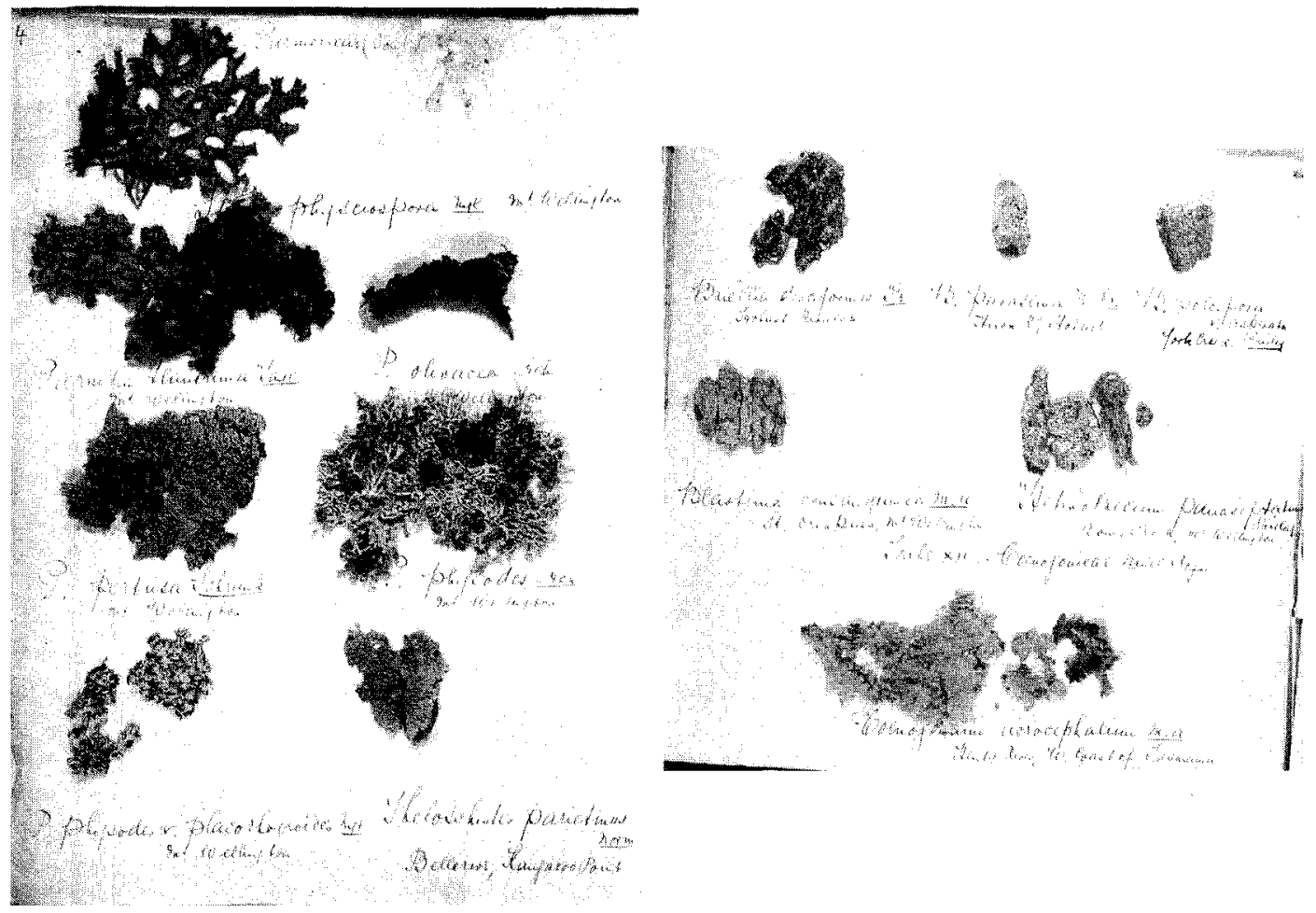

PLATE I

Selected pages from Shirley's album of Tasmanian lichens, annotated in his own handwriting.

Weymouth is atso responsible for more than half of the Mt Wellington lichen collections. The order of the lichen specimens in the album, and their annotations, exactly follow Shirley's paper in 1894, leaving no doubt that this is the collection of specimens upon which the work was based.

The collection is an extremely valuable and important historical resource in Tasmanian lichenology. Firstly, it contains several type specimens of endemic Tasmanian taxa. Several of the new records in the collection are unusual and suspect (e.g. Sphaerophorus fragilis) but were maintained in subsequent Tasmanian checklists, e.g. Wetmore (1963) and Filson (1986b). Finally, the collection represents information on the lichen flora of Mt Wellington for the period up to 1892 . Massive changes in the area's vegetation have occurred since that time as a result of at least three wildfires (the first in the summer of 1897-98, W. D. Jackson, pers. comm.) and the gradual encroachment of the suburbs of Hobart, at least in the foothills. Accurate historical floristic data, particularly on lichens, will aid in assessing the severity of these changes.

In the present paper, results of a reexamination and re-determination of Shirley's lichen collection are reported.

\section{MATERIALS AND METHODS}

Lichens from Shirley's collection were reexamined in the light of recent studies made on the Tasmanian lichen flora (Kantvilas 1985, Kantvilas \& James 1987), and present-day accounts from Australasia and the Northern Hemisphere. Identifications were checked where possible against type specimens, type descriptions and/or reliably identified material. Thin-layer chromatography was undertaken using standard methods (Culberson 1972). 


\section{RESULTS AND DISCUSSION}

The order of species in the following discussion is that adopted by Shirley (1894), and in his mounted collection. Species are listed under Shirley's original nomenclature. Results are summarised in table 1, giving currently accepted names.

\section{(1) Leptogium chloromelum var. granulare Muill. Arg.}

The specimen has an indistinct, small, squamulose thallus and apothecia with sparsely ciliate margins. Spores are simple, 17.5-22 x $9.5-11 \mu \mathrm{m}$ with a warted epispore. The specimen is clearly Psoroma hypnorum (Vahl) S.F. Gray aggr., differing from Northern Hemisphere material of that name (see Jørgensen 1978) chiefly in the smaller spores. As Shirley's is the only record of this species of Leptogium from Tasmania, it can now be confidently deleted from the checklist.

\section{(2) Calicium victoriae C. Knight ex F. Wilson}

Although in very poor condition, the specimen accords with the original description (Wilson 1889). The species is now known as Mycocalicium victoriae (C. Knight ex F. Wilson) Tibell (Tibell 1984, 1987).

\section{(3) Sphaerophoron compressum Ach.}

The specimen contains stictic and constictic acids and sphaerophorin (by tlc) and accords with Sphaerophorus melanocarpus (Swartz) DC., in every respect.

\section{(4) Sphaerophoron coralloides Pers.}

This specimen has flattened main branches, veiled ventral mazaedia and brown spores, $12 \mu \mathrm{m}$ diameter. It contains sphaerophorin and protocetraric acid (by tlc) and is Sphaerophoros insignis Laurer, a common Tasmanian species.

\section{(5) Sphaerophoron fragile Pers.}

Ohlsson (1974) regards Sphaerophorus fragilis as a Northern Hemisphere arctic/alpine species and hence Shirley's record is unusual. The diminutive BRI specimen is in very poor condition, possesses cephalodia and contains atranorin and perlatolic acid. There is no doubt that it is a juvenile Stereocaulon, probably $S$. ramulosum, and thus Sphaerophorus fragilis should now be deleted from the Tasmanian checklist.
(6) Sphaerophoron tenerum Laurer = Sphaerophorus tener Laurer

(7) Baeomyces heteromorphus Nyl. ex Church. Bab. \& Mitten

\section{(8) Stereocaulon ramulosum (Swartz)} Rauschel

The specimen contains atranorin and perlatolic acid and is typical of the species in Tasmania.

\section{(9) Stereocaulon proximum var. macro-} carpioides (Nyl.) Hue

This taxon was considered synonymous with S. ramulosum by Lamb (1977). Shirley's specimen contains atranorin and perlatolic acid and falls within the range of this variable species.

\section{(10) \& (11)}

These specimens have been excised from Shirley's album some time in the past and could not be checked. They can be referred to Cladia aggregata (Swartz) Nyl., and C. schizopora (Nyl.) Nyl. respectively, both of which are widespread in Tasmania.

\section{(12)-(22) Cladonia spp.}

These 11 specimens have also been removed from the album, leaving only the bases of the cut pages. Cladonia in Australia is currently under revision (by Dr A. W. Archer, Sydney), and it is likely that many of Shirley's names will ultimately be deleted from the Tasmanian checklist.

\section{(23) Usnea dasypogoides Nyl. ex Crombie}

The specimen contains usnic and salazinic acids and has sparsely pseudocyphellate and pseudoisidiate branch tips. It is provisionally referred to Usnea arida Motyka in the sense of Kantvilas \& James (1987) and Galloway (1985), although in general the genus is still very poorly known in Australia.

\section{(24) Stictina cinnamomea Rich. [= Pseudo-} cyphellaria cinnamomea (A. Rich.) Vainio]

Shirley's specimen has sparse marginal phyllidia, lacks a well-developed midrib on the lower surface, and accords with Pseudocyphellaria dissimilis (Nyl.) D. Galloway \& P. James. These two species are easily confused (Galloway 1985) and although $P$. cinnamomea (A. Rich.) Vainio was often reported in early Tasmanian literature (as Stictina cinnamomea), I have yet to see any Tasmanian material of this species. 


\section{TABLE 1}

\section{Results of re-examination of Shirley's Tasmanian specimens}

Code: 1 - status unchanged; 2 - nomenclatural change; 3 - re-determination.

\section{Code Shirley's determination (1894)}

\section{New determination or name}

Psoroma hypnorum (Vahl.) S.F. Gray aggr.

Mycocalicium victoriae (Knight) Tibell

Sphacrophorus melanocarpus (Swarte) DC.

Sphaerophorus insignis Laurer

Stereocaulon ramulosum (Swartz) Räuschel

Sphaerophorus tener Laurer

Baeomyces heteromorphus Nyl. ex Church. Bab. \& Mitten

Stereocaulon ramulosum (Swartz) Räuschel

Stereocaulon ramulosum Ach.

Stereocaulon ramulosum (Swartz) Räuschel

?Usnea arida Motyka

Pseudocyphellaria dissimilis (Nyl.) D. Galloway \& James

Pseudocyphellaria glabra (J.D. Hook. \& Taylor) Dodge

Pseudocyphellaria multifida (Nyl.) D. Galloway \& P. James

Pseudocyphellaria faveolata (Delise) Malme Pseudocyphellaria hillardierei (Delise) Räsänen

Parmelia tenuirima J.D. Hook. \& Taylor

Menegazzia testacea P. James \& D. Galloway

Menegazzia weindorferi (Zahlbr.) R. Sant.

Hypogymnia mundata (Nyl.) Rassad.

Hypogymnia turgidula (Bitter) Elix

Xanthoria ligulata (Körber) P. James

Psoroma microphyllizans (Nyl.) D. Galloway

Psoroma microphyllizans (Nyl.) D. Galloway

Placopsis brevilobata (Zahlbr.) Lamb

Caloplaca cinnaharina (Ach.) Zahlbr.

Lecidea immarginata $\mathrm{R} . \mathrm{Br}$.

Lecidea laeta Stirton

Lecidea cera-rufa (Shirley) Zahlbr.

Catillaria tasmanica Räsänen

Bacidia weymouthia (Shirley) Zahlbr.

Catinaria grossa (Pers. ex Nyl.) Vainio

Buellia disciformis (Fr.) Mudd.

Rinodina asperata (Shirley) Kantvilas

Megaloblastenia marginifle.xa (J.D. Hook. \&

Taylor) Sipman

Austroblastenia pauciseptata (Shirley) Sipman

Coenogonium implexum Nyl.

Arthothelium ilicinum (Taylor) P. James

Chiodecton colensoi (Massal.) Müll. Arg.

Pyrenula galactina (Shirley) Kantvilas 


\section{(25) Sticta freycinetii Delise}

This specimen is Pseudocyphellaria glabra (J.D. Hook. \& Taylor) Dodge $[=P$. delisea (Fée) D. Galloway \& P. Jamesl, a common austral species related to $P$. freycinetii (Delise) Malme. The two taxa have been frequently confused but Pseudocyphellaria freycinetii is a South American taxon while $P$. glabra is known from Australasia, cool temperate South America and the subantarctic islands (Galloway \& James 1986).

\section{(26) Sticta dissimulata Nyl.}

This specimen is referable to Pseudocyphellaria multifida (Nyl.) D. Galloway \& P. James [ = P. subvariabilis (Ny].) Vainio], a common Tasmanian wet forest lichen.

\section{(27) Sticta fossulata Dufour}

This taxon is a synonym of Pseudocyphellaria billardierei (Delise) Räsänen (Galloway 1988). Shirley's specimen contains physciosporin (Code B of Wilkins \& James 1979) and represents typical material of $P$. faveolata (Delise) Malme.

\section{(28) Sticta fossulata var. physciospora Nyl.}

This name is a synonym of Pseudocyphellaria physciospora (Nyl.) Malme, a species known only from the subantarctic islands of New Zealand, and Juan Fernandez (see Galloway 1988). Shirley's specimen has Code C chemistry (see Wilkins \& James 1979, methyl evernate, tenuiorin etc.) and is P. billardierei (Delise) Räsänen.

\section{(29) Parmelia tenuirima J.D. Hooker \& Taylor}

The specimen is typical of this common Australasian species and contains atranorin and salazinic acid.

\section{(30) Parmelia olivacea Ach.}

Parmelia olivacea is confined to the Northern Hemisphere (Esslinger 1977). Most records of the species in Tasmania are from rocks or soil (e.g. Wilson 1893) and probably refer to Parmelia pulla Ach. I= Neofuscelia pulla (Ach.) Esslinger], the most common brown Parmelia s.lat. in Tasmania. Shirley's specimen is on a twig and is Menegazzia testacea P. James \& D. Galloway. It has characteristic 2-spored asci and contains atranorin, stictic acid and menegazziaic acid (by tlc).

\section{(31) Parmelia pertusa Schrank}

This name, a synonym of the Northern Hemisphere species Menegazzia terebrata (Hoffm.) Massal., was widely misapplied in the literature to many Tasmanian species of Menegazzia. Shirley's specimen is of $M$. weindorferi (Zahlbr.) R. Sant., and contains protolichesterinic and lichesterinic acids and atranorin.

\section{(32) Parmelia physodes Ach.}

The name Parmelia physodes has been generally misapplied in the past to several Tasmanian species of Hypogymnia. Shirley's specimen has discrete, elongated, solid lobes, lacks soredia and has a Pd medulla, all features of $H$. mundata (Nyl.) Rassad.

\section{(33) Parmelia physodes var. placorhodioides} Nyl.

Elix (1979) considered this name to be a synonym of Hypogymnia billardierei (Mont.) Filson. However, Shirley's specimen has hollow lobes, contiguous at the centre of the thallus but discrete at the margins, a Pd medulla, and is $H$. turgidula (Bitter) Elix, the most common species of Hypogymnia in Tasmania's wet forests.

\section{(34) Theloschistes parietinus Norm.}

\section{[= Xanthoria parietina (L.) Th.Fr.]}

This specimen is referred to the common saxicolous coastal species Xanthoria ligulata (Körber) P. James (previously called $X$. ectanea (Ach.) Räsänen by Filson 1969). It has narrow convex lobes with down-turned apices and sparsely lobulate margins and is thus distinct from $X$. parietina.

(35) \& (36) Psoroma sphinctrinum Nyl. and Psoroma sphinctrinum var. pholidotoides Nyl.

Specimens of numbers 35 and 36 both have laciniate, radiating lobes with Iobulate margins and small, contiguous, globose or flattened phyllidia and thus accord well with P. microphyllizans (Nyl.) D. Galloway, in the sense of Kantvilas \& James (1987).

\section{(37) Placodium gelidum Körber I=Placopsis} gelida (L.) Lindsay]

The genus Placopsis is poorly known in Tasmania and, as no spores could be found in Shirley's scanty specimen, identification was impossible. The specimen is cream-coloured, 
esorediate, with well-developed, convex, marginal lobes, brownish-cream, pruinosc apothecia and a $\mathrm{C}^{+}$red medulla. It is probably better referred to $P$. brevilobata (Zahlbr.) Lamb (sensu Galloway 1985).

(38) Callopisma cinnabarina Müll. Arg. [ Caloplaca cinnabarina (Ach.) Zahlbr.]

The genus Caloplaca is poorly known in Tasmania. Shirley's specimen is of a saxicolous coastal species lacking marginal lobes and with spores $11.5-14.5 \times 7-8.5 \mu \mathrm{m}$, with septa 2.5-5.0 $\mu \mathrm{m}$ thick.

\section{(39) Biatora immarginata R.Br. [=Lecidea immarginata $\mathrm{R} . \mathrm{Br}$.]}

First described from New South Wales, Lecidea immarginata is widespread in wet forest in Tasmania and will be discussed in detail in a forthcoming paper on rainforest species.

\section{(40) Biatora russula Ach. [= Lecidea russula Ach.]}

Although no mature spores were seen, all other features indicate that Shirley's specimen is the widespread and common Australasian species, Lecidea lacta Stirton. The name Lecidea russula should be deleted from the Tasmanian checklist.

\section{(41) Biatora cera-rufa Shirley [=Lecidea cera-rufa (Shirley) Zahlbr.]}

This distinctive species is known to me only from Shirley's type collection. In addition to Shirley's notes, it has the following anatomical characteristics: epithecium red-brown, unchanged in $\mathrm{KOH}$; hymenium colourless, $\mathrm{I}^{+}$deep blue, 80-100 $\mu \mathrm{m}$ thick; hypothecium colourless to pale yellow-brown, 60-120 $\mu \mathrm{m}$ thick, unchanged in $\mathrm{KOH}$; paraphyses simple, separating easily in $\mathrm{KOH}$; spores simple, broadly ellipsoid, 16.5-19.5 x 9.5-12 $\mu \mathrm{m}$ (somewhat larger than in Shirley's description). Thallus chemistry includes a $U \mathrm{~V}^{+}$ unknown substance.

Holotype: Tasmania. On bark, Bower Track, Mt Wellington, W.A. Weymouth No.141 (Filson 1986a: 26). BRI 351374 !

(42) Patellaria melanotropa Nyl. [= Catillaria melanotropa (Nyl.) Zahlbr.]

Shirley's specimen is in extremely poor condition and no mature spores were found. However, in gross morphology, habitat ecology and thallus chemistry (atranorin) it accords well with Catillaria tasmanica Räsänen, a common Tasmanian species which still abounds in Shirley's collecting locality (Mt Wellington).

(43) \& (44) Patellaria taitensis Mnt. [=Megalospora sulphurata Meyen] and Patellaria biclipea Shirley $1=$ Megalospora biclipea (Shirley Zahlbr.]

Specimens 43 and 44 are both missing from the album and there is no sign (e.g. cut pages, blank spaces) that they were ever present. The missing specimens were sought without success in the herbaria of Melbourne, Sydney and Brisbane, all of which house some of Shirley's material. According to Sipman (1983), Megalospora sulphurata does not occur in Tasmania, although Shirley's name may have been misapplied to another species of Megalospora. However, a recent search of his collecting area did not locate any species of this genus. The loss of the second specimen is more acute as it represents the holotype, as well as the only specimen of Megalospora biclipea. However, Shirley's description, and his observation that it is related to Catinaria grossa (Pers. ex Nyl.) Vainio, suggests that the species is most likely a Catinaria s.lat. (see also Sipman 1983), possibly even a shade form of Catillaria tasmanica Räsänen, a species occurring very commonly in the area today. A copy of Shirley's manuscript, in William Weymouth's hand, was found amongst some of Weymouth's papers (donated by Mrs M. Bennet, Cradoc, Tasmania). In this copy, the text concerning the two missing specimens is also missing, except for an inserted note referring to some additional pages. Thus it appears that these two lichens were never part of the original collection but were included later. How or why Weymouth possessed a handwritten version of the paper is unclear. Perhaps his contribution to the text was greater than indicated; after all, the specimens were almost exclusively his, whilst Shirley's main contribution was in their identification. As Shirley was only a corresponding member of the Royal Society of Tasmania, it is possible that Weymouth may have revised and submitted the paper on his behalf, although no record of the latter was found in the Society's minutes or proceedings.

\section{(45) Patellaria weymouthii Shirley} [= Bacidia weymouthii (Shirley) Zahlbr.]

Bacidia weymouthii is a common wet forest species of smooth bark and is discussed in detail in Kantvilas (1985). 
Lectotype (selected here): Tasmania. On bark, St Crispins, Mt Wellington, W. A. Weymouth, BRI 351374 !

lsotype: On bark of tree, St Crispins, Mt Wellington, Tasmania. W.A. Weymouth 112 , 10/3/91, MEL 7048! (Filson 1986a: 219).

A third collection of this species (cited in Shirley 1894) was not located.

\section{(46) Bucllia disciformis (Fr.) Mudd.}

Examination of Shirley's specimen revealed I-septate, hyaline spores, indicating that it is not a Buellia. Rather, it appears to be a species of Catillaria s.lat,, with the following apothecial characters: epithecium brown-black, unchanged in $\mathrm{KOH}$; hymenium colourless, $120-190 \mu \mathrm{m}$ thick; hypothecium greenish-black, opaque, unchanged in $\mathrm{KOH}$; outer edge of excipulum similarly coloured but colourless within; spores hyaline, 1-septate, $26.5-34 \times 12-16 \mu \mathrm{m}$ with a distinct wall, c. $1 \mu \mathrm{m}$ thick. The specimen closely resembles Catinaria grossa (Pers. ex Nyl.) Vainio (see Poelt \& Vezda 1981) although the apothecia are rather small and mostly $<1$ mm diameter. A second specimen of the species is included under "Heterothecium pauciseptatum" (see no.50) below.

\section{(47) Buellia parasema Th.Fr. [B. parasema} (Ach.) De Not.]

Santesson (1984) placed Buellia parasema as a synonym of $B$. disciformis (Fr.) Mudd., and Shirley's specimen appears to accord with the description of that species given in Poelt (1969). Its spores are $16.5-24 \times 7-10 \mu \mathrm{m}$, dark brown, thinwalled; epithecium dark brown; hymenium colourless to pale brown, 70-95 $\mu \mathrm{m}$ thick, interspersed with oil droplets; hypothecium dark brown. The genus Buellia is still poorly known in Tasmania and requires detailed study and revision.

\section{(48) Buellia polospora var. asperata Shirley}

Sheard (1967) placed Buellia polospora (Leighton) Shirley as a synonym with Rinodina biloculata (Nyl.) Sheard. However. Shirley's specimen differs from authentic $R$. biloculata in the larger, polarilocular (not placodiomorph) spores, colourless, thicker hypothecium, and the presence of a persistent thalline margin. Corticolous species of Rinodina are poorly known in Tasmania. However, until a revision is undertaken, in my opinion Shirley's taxon warrants specific rank:
Rinodina asperata (Shirley) Kantvilas comb. nov. Basionym: Buellia polospora var. asperata Shirley, Pap. Proc. R. Soc. Tasm. (1893): $218,1894$.

Thallus thin, rather scurfy, pale grey, prothallus absent. Apothecia lecanorine, sessile, dispersed, to $0.4 \mathrm{~mm}$ diam. Disc plane to slightly convex, brownish black. Thalline margin thin, entire, somewhat discoloured in older apothecia. Hymenium $70-85 \mu \mathrm{m}$ thick, colourless. Epithecium red-brown. Hypothecium colourless, to $120 \mu \mathrm{m}$ thick at centre of apothecia. Paraphyses c. $1 \mu \mathrm{m}$ thick, apices markedly capitate, 2-3 $\mu \mathrm{m}$ thick. Spores brown, 8 per ascus, polarilocular, very thick walled, lumina rounded when mature, 16.5-22 x 8.5-13 $\mu \mathrm{m}$.

Holotype: Tasmania. On bark, Fork Creek, W.A Weymouth No.144, BRI!

Isotype: G (see Filson 1986a: 33).

The species is known only from the type collection from the southern slopes of $\mathrm{Mt}$ Wellington.

(49) Blastenia consanguinea Müll. Arg.

Shirley's specimen is Megaloblastenia marginiflexa (J.D. Hook. \& Taylor) Sipman. As this was the only Australian record of Blastenia consanguinea, this name can now be deleted from the Australian checklist (Filson 1986b).

\section{(50) Heterothecium pauciseptatum Shirley} [=Austroblastenia pauciseptata (Shirley) Sipman]

When Sipman (1983) selected a specimen in NSW as the type (see also Filson 1986a: 96), he was unaware of the existence of Shirley's album collection. Given that Shirley's paper was based on this collection, the album specimen should be considered as holotype, whereas the NSW specimen (NSW L4385) is correctly an isotype. The specimen of Austroblastenia is mounted in the album beside a specimen of Catinaria grossa s.lat.

\section{(51) Coenogonium acrocephalum Müll. Arg.}

Shirley's specimen, representing the only record of this taxon from Tasmania, is identical with reliably identified (by Dr A. Vezda, Brno) material of $C$. implexum Nyl., the common and widespread species of Coenogonium in Tasmania. Other species of the genus recorded from Tasmania in earlier Iiterature are $C$. linkii Ehrenb. ex Nees and $C$. rigidulum Muill. Arg. It is likely that these records also refer to $C$. implexum. 


\section{(52) Arthonia multiformis Shirley}

Shirley's specimen is the type of this species and is identical with reliably identified material (by Dr A. Vezda, Brno, and Mr P.W. James, London) of Arthothelium ilicinum (Taylor) P. James (see Kantvilas 1985). The species has characteristic spores with an enlarged terminal locule and lacks longit udinal septa.

Holotype: Tasmania. On bark, near Hobart, W.A. Weymouth No. 111, BRI 351373! (see also Filson 1986a: 16).

\section{(53) Chiodecton perplexum Nyl.}

This specimen is in poor condition but appears to be identical with Chiodecton colensoi (Mass al.) Müll.) Arg., a common wet forest species in Tasmania, also known (and first described) from New Zealand.

\section{(54) Pseudopyrenula galactina Shirley}

This specimen has brown, mature spores and slender, simple paraphyses, suggesting it is a species of Pyrenula. On the basis of Shirley's specimen, and recent collections, the species is redescribed below.

Pyrenula galactina (Shirley) Kantvilas comb.nov. Basionym: Pseudopyrenula galactina Shirley, Pap. Proc. R. Soc. Tasm. (1893): 219, 1894.

Thallus crustose, thin to rather thick, deeply cracked, greyish white, pale yellowish or olivegrey, forming spreading patches to $10 \mathrm{~cm}$ across, not delimited at margins. Perithecia numerous, immersed, obscured by cortex, occasionally subemergent, becoming eroded, excavate and forming blackish pits to c. $0.3 \mathrm{~mm}$ diam. Ostiole central, minute, punctate, blackish, often with a grey rim. Paraphyses slender, simple to sparingly branched, free. Spores soon becoming brownish, ellipsoid, 14-22(-26) x 5-10 $\mu \mathrm{m}, 4-10 c u l a r$, not constricted at septa, arranged in the ascus obliquely in a single row. Locules lenticellular, rhomboid or hexagonal, \pm equal sized.

Chemistry: Thallus $\mathrm{K}+$ orange-brown, $\mathrm{KC}-\mathrm{Pd} \mathrm{C}$, $\mathrm{UV}^{+}$orange (sometimes faintly); lichexanthone (by llc).

Holotype: Tasmania. On bark, St Crispins, W. A. Weymouth, No.113, BRI 351370! (Filson 1986a: 248).

Additional specirnens examined: Tasmania. Mt Victoria Road, on Phyllocladus aspleniifolius in rainforest, $780 \mathrm{~m}$, 9.xii.1981, G. Kantvilas
1097/81, herb. Kantvilas, BM. Ben Ridge Road, on Nothofagus cunninghamii in rainforest, $850 \mathrm{~m}, 10 . x \mathrm{i} .1981$, G. Kantvilas $1188 / 81$, herb. Kantvilas.

\section{(55) Pyrenula chloroplaca Shirley}

This distinctive species is still known only from Shirley's type specimen. It has a yellowishcream thallus, $\mathrm{UV}^{+}$bright orange (suggesting lichexanthone) and brown, 4-locular spores, 14-22 $x$ 8-12 $\mu \mathrm{m}$, the pical locules very small. Two collections (both by Weymouth) are specified in Shirley's paper but the whereabouts of the second is unknown.

Lectotype (selected here): Tasmania. On bark, St Crispins, W.A. Weymouth No.114, BRI 351369! (Filson 1986a: 252).

The pyrenocarpous lichens as a group remain poorly understood in Tasmania and require considerable further collection and study.

\section{ACKNOWLEDGEMENTS}

I thank Dr D. J. Galloway, Mr P. W. James, Dr S. J. Jarman and Dr A. E. Orchard for helpful comments on various aspects of the work, and the curators and staff of the Queensland Herbarium and Tasmanian Herbarium for arranging loans of specimens. I also thank Mrs $\mathrm{M}$. Bennet for providing original extracts from $\mathrm{Mr}$ W. A. Weymouth's papers. The receipt of a National Research Fellowship is gratefully acknowledged.

\section{REFERENCES}

BASSETT HULL, A.F., 1923: Presidential address. Proc. Linn. Soc. N.S.W. 48: vii-viii.

CULBERSON, C.F., 1972: Improved conditions and new data for the identification of lichen products by a standardised thin-layer chromatographic method. J. Chromatogr. 72: 113-125.

ELIX, J.A., 1979: A taxonomic revision of the lichen genus Hypogymnia in Australasia. Brunonia 2: 175-245.

ESSLINGER, T.L., 1977: A chemosystematic revision of the brown Parmeliae. J. Hattori bot. Lab. 42: 1-211.

FILSON, R.B., 1969: A review of the genera Teloschistes and Xanthoria in the lichen family Teloschistaceae in Australia. Muelleria 2: 65-115.

FILSON, R.B., 1986a: INDEX TO TYPE SPECIMENS OF AUSTRALIAN LICHENS: 1800-1984. Bureau of Flora and Fauna, Canberra.

FILSON, R.B., 19866: CHECKLIST OF AUSTRALIAN LICHENS. Second edition, National Herbarium of Victoria, Melboume. 
GNLOWAY, D.J., 1985: FLORA OF NEW ZEALAND LICHENS. Government Printer, Wellington.

GALLOWAY, D.J., 1988: Studies in Pseudocyphellaria (lichens). 1. The New Zealand species. Bull. Br. Mus. nat. Hist. (Bot.) 17: 1-267.

GALLOWAY, D.J. \& JAMES, P.W., 1986: Species of Pseudocyphellaria Vainio (Lichenes) recorded in Delise's "Histoire des Lichens: Genre Sticta". Nova Hedwigia 42: 423-490.

JøRGENSEN, P.M., 1978: The lichen family Pannariaceae in Europe. Opera Botanica 45: 1-124.

KANTVILAS, G., 1983: A brief history of lichenology in Tasmania. Pap. Proc. R. Soc. Tasm. 117: 41-51.

KANTVILAS, G., 1985: Studies on Tasmanian rainforest lichens. Unpubl. Ph.D. thesis, Univ. Tasm.

KANTVILAS, G. \& JAMES, P.W., 1987: The macrolichens of Tasmanian rainforest: key and notes. Lichenologist 19: $1-28$.

LAMB, I.M., 1977: A conspectus of the lichen genus Stereocaulon (Schreb.) Hoffm. J. Hattori bot. Lab. 43: $191-335$.

OHLSSON, K., 1974: A revision of the lichen genus Sphaerophorus. Unpubl.Ph.D. thesis, Michigan State Univ.

POELT, J., 1969: BESTIMMUNGSSCHLÜSSEL EUROPÄISCHER FLECHTEN. J. Cramer, Vaduz.

POELT, J. \& VEZDA, A., 1981: BESTIMMUNGSSCHLÜSSEL EUROPÄISCHER FLECHTEN. ERGANZUNGSCHEFT II. J. Cramer, Vaduz.

SANTESSON, R., 1984: THE LICHENS OF SWEDEN AND NORWAY. Swedish Museum of Natural History, Uppsala and Stockholm.
SHEARD, J.W., 1967: A revision of the lichen genus R inodina (Ach.) Gray in the British Isles. Lichenologist 3: $328-367$

SHIRLEY, J., 1888-90: The lichen flora of Queensland I-IV.Proc. R. Soc. Qld 5:80-110;6:5-55, 129-145, $165-218$.

SHIRLEY, J., 1893: A list of the known lichens of Tas mania. Pap. Proc. R. Soc. Tasm. (1892): 179-191.

SHIRLEY, J., 1894: Notes on Tasmanian lichens. Pap. Proc R. Soc. Tasm. (1893): 214-219.

SHIRLEY, J., 1918: The thallus of the genus Parmelia. Pap. Proc. R. Soc. Tasm. (1918): 53-68.

SIPMAN, H.J.M., 1983: A monograph of the lichen family Megalosporaceae. Biblioth. Lich. 18: 1-241.

TIBELL, L., 1984: A reappraisal of the taxonomy of Caliciales. Beih. Nova Hedwigia 79: 597-713.

TIBELL, L., 1987: Australasian Caliciales. Symb. Bot. Upsal 27: $1-279$.

WETMORE, C.M., 1963: Catalogue of the lichens of Tasmania. Rev. Bryol. et Lichenol. 32: 223-264.

WHITE, C.T., 1922: Presidential address. Proc. R. Soc. Qld 34: $2-3$.

WILKINS, A.L. \& JAMES, P.W., 1979: The chemistry of Pseudocyphellaria impressa s.lat. in New Zealand. Lichenologist 11(3): 271-281.

WILSON, F.R.M., 1889: A description of forty-one Victorian lichens new to science. Vict. Nat. 6: 61-69.

WILSON, F.R.M., 1893: Tasmanian lichens. Pap. Proc. R. Soc. Tasm. (1892): 133-178.

(accepted 6 February 1988) 